Volume VII , Nomor 1, Juni 2021 : Hal 42-49

Jurnal Utile

https://jurnal.ummi.ac.id/index.php/JUT

\title{
Pengembangan Media Pembelajaran Interaktif Berbasis Macromedia Flash Materi Kewargaan Digital Di SMK Pasim Plus Sukabumi
}

\author{
Maryam Sarah Fallensky ${ }^{1}$, Arif Yudianto ${ }^{2}$, Dadan Rahmat ${ }^{3}$ \\ Program Studi Pendidikan Teknologi Informasi Universitas Muhammadiyah Sukabumi \\ Jl. R. Syamsudin, S.H. No. 50, Cikole, Kec. Cikole Kota Sukabumi \\ sarahhyesong@gmail.com
}

\begin{abstract}
Abstrak: Tujuan dari penelitian ini yaitu untuk mengembangkan media pembelajaran interaktif materi Kewargaan Digital yang layak dan sesuai untuk peserta didik kelas X OTKP 1 SMK Pasim Plus Sukabumi Kelayakan dari media pembelajaran interaktif ini ditinjau dari aspek kevalidan. Metode penelitian yang digunakan menggunakan metode penelitian dan pengembangan Research and Development $(R \& D)$ yang dibatasi hanya sampai 7 tahap dari yang seharusnya 8 tahap karena kendala waktu dan biaya, tahap - tahap yaitu potensi dan masalah, pengumpulan data, desain produk, validasi desain, revisi desain, uji coba produk, revisi produk. Media pembelajaran interaktif diujicobakan di kelas X OTKP 1 SMK Pasim Plus Sukabumi. Instrumen yang digunakan adalah lembar validasi media, lembar validasi materi, dan angket respon pengguna. Pengguna adalah peserta didik kelas X OTKP 1 SMK Pasim Plus Sukabumi dengan jumlah 8 orang peserta didik dalam uji coba kelas kecil. Kriteria kelayakan produk yang dikembangkan pada penelitian ini ditentukan dengan nilai minimal 3,7 dari skala 5 dengan kategori layak. Hasil validasi oleh ahli media yaitu 4,13 (sangat layak), validasi ahli materi yaitu 5 (sangat layak), dan penilaian uji coba kelas kecil dengan 8 orang peserta didik yaitu 4 (layak). Dengan begitu, media pembelajaran interaktik materi Kewargaan Digital ini sangat layak untuk digunakan sebagai media pembelajaran.
\end{abstract}

Kata kunci: Macromedia flash, media pembelajaran interaktif, Kewargaan Digital.

Abstract: The purpose of this research is to develop interactive learning media for Digital Citizenship material that is feasible and suitable for class X OTKP 1 students of SMK Pasim Plus Sukabumi. The feasibility of interactive learning media is viewed from the validity aspect. This research method used uses the Research and Development $(R \& D)$ which is limited to 7 stages from the 8 due to time and coast constranints, these stages include potentials and problems, data collection, product design, design validation, design revision, product testing, product revision. Interactive learning media were tried out in class X OTKP I SMK Pasim Plus Sukabumi. The instruments used were media validation sheets, material validation sheets, and user response questionnaires. Users are students of class X OTKP 1 SMK Pasim Plus Sukabumi with a total of 8 students in the small class trial. The product eligibility criteria developed in this study were determined with a minimum value of 3.7 from a scale of 5 with the feasible category. The results of the validation by the media expert were 4.13 (very feasible), the material expert validation was 5 (very feasible), and the small class trial assessment with 8 students was 4 (feasible). That way, this interactive learning media for Digital Citizenship material is very suitable to be used as a learning medium. Keyword: Macromedia flash, interactive learning media, Digital Citizenship.

History :

Submit tgl 13 Februari 2021, revisi 16 Februari 2021, diterima 16 Februari 2021 


\section{PENDAHULUAN}

Pendidikan adalah usaha sadar dan terencana untuk mewujudkan suasana belajar dan proses pembelajaran agar peserta didik secara aktif mengembangkan potensi dirinya untuk memiliki kekuatan spiritual, keagamaan, pengendalian diri, kepribadian, kecerdasan, akhlak mulia, serta keterampilan yang diperlukan dirinya, masyarakat, bangsa, dan negara. Dalam konteks kehidupan bernegara pendidikan berdasarkan pancasila dan Undang Undang Dasar Negara Republik Indonesia tahun 1945 yang berakar pada nilai - nilai agama, kebudayaan nasional Indonesia dan tanggap terhadap tuntutan perubahan zaman. (Teguh Triwiyanto, 2014:113).

Terhadap tuntutan zaman yang sudah lebih modern seperti saat ini pendidikan jauh lebih maju dengan adanya teknologi yang masuk di dunia pendidikan. Dalam proses mengembangkan potensi peserta didik pun tidak dapat di pungkiri teknologi merupakan salah satu aspek utama dalam mengoptimalkan potensi alami yang dimiliki oleh peserta didik.

Pendidikan dan teknologi sangat erat hubungan nya di era modern seperti sekarang dengan adanya bantuan teknologi seperti sekarang ini memudahkan lembaga pendidikan dan peserta didik dalam melakukan proses pembelajaran,

Kecendrungan perubahan dan inovasi dalam dunia pendidikan akan terus terjadi dan berkembang dalam memasuki abad ke- 21 sekarang ini. Perubahan tersebut antara lain: lebih mudah dalam mencari sumber belajar, lebih banyak pilihan untuk menggunakan dan memanfaatkan ICT, makin meningkatnya peran media dan multimedia dalam kegiatan pembelajaran. (Budiman, 2017). Pemberian sumber belajar yang lebih bervariasi dan kemudahan dalam menggunakannya menjadikan teknologi sebagai alat bantu pendidikan yang sangat bisa diandalkan oleh lembaga pendidikan khususnya untuk sekolah menengah kejuruan.

Sesuai dengan pernyataan tersebut peneliti melakukan obeservasi saat melakukan program magang di SMK Pasim Plus Sukabumi. Dari hasil observasi sekolah tersebut sangat unggul dalam memanfaatkan teknologi. Terbukti dengan fasilitas penunjang pembelajaran yang sudah sangat memadai seperti mempunyai 23 ruang kelas, 4 laboratorium komputer, 2 ruang laboratorium multimedia, 1 ruang perpustakaan konvensional, 1 ruang perpustakaan media, dan masing - masing 1 ruang kerja praktik untuk setiap program keahlian. Dengan memiliki 6 program keahlian yaitu akuntansi, administrasi perkantoran, teknik komputer dan jaringan, rekayasa perangkat lunak, broadcasting, dan film animasi. Dengan fasilitas seperti ini SMK Pasim Plus Sukabumi bisa dibilang unggul dalam penggunaan teknologi.

Namun dibalik unggulnya fasilitas tersebut masih ada kekurangan yang dimiliki yaitu salah satunya pengemasan materi bahan ajar yang kurang menarik dan bervariasi. Pembelajaran masih dilakukan dengan cara konvensional yaitu peserta didik 
mempelajari materi hanya dengan modul dan metode ceramah.

Pemilihan materi yang peneliti pilih untuk dikembangkan sebagai media pembelajaran interaktif yaitu materi Kewargaan Digital dikarenakan materi tersebut dianggap sepele oleh para siswa dan tidak banyak diulas oleh guru, mungkin bila materi tersebut dikemas dengan menggunakan sebuah media pembelajaran yang menarik hal tersebut akan meningkatkan perhatian siswa terhadap materi ini. Karena materi ini terbilang cukup penting mengingat situasi dan kondisi saat ini mengharuskan kita menjadi warga digital sepenuhnya.

Sesuai dengan penelitian dan observasi yang di lakukan di kelas X OTKP 1 SMK Pasim Plus Sukabumi masalah yang di temukan yaitu: Pemberian materi hanya berupa softfile modul dan tidak adanya media pembelajaran untuk materi Kewargaan Digital. Pemberian materi yang berupa teori kadang tidak optimal di berikan oleh guru di karenakan guru lebih memilih untuk langsung melakukan praktik sehingga teori yang seharusnya di berikan untuk kemampuan kognitif peserta didik menjadi tidak tersampaikan dengan optimal. Sedangkan dalam materi ini tidak ada pembelajaran yang mengharuskan praktik tetapi hanya pembahasan teori. Oleh karena itu pembuatan media pembelajaran interaktif untuk pembelajaran ini mampu mengganti format pemberian materi yang hanya sebatas modul menjadi sebuah materi yang lebih menarik untuk melakukan pembelajaran sendiri dan dapat mengganti materi yang menggunakan metode ceramah menjadi materi yang lebih menyenangkan dengan menggunakan media pembelajaran interaktif. Sesuai dengan pernyataan menurut Ali Muhson peran media dalam proses pembelajaran menjadi penting karena akan menjadikan proses pembelajaran tersebut menjadi lebih bervariasi dan tidak membosankan. (Ali Muhson, 2010). Penggunaan media interaktif yang di dalamnya berupa text, audio, dan visual mampu menjelaskan materi dengan abtraksi yang rumit.

Solusi dari permasalahan tersebut yaitu peneliti ingin membuat media pembelajaran interaktif dengan menggunakan salah satunya yang peneliti gunakan yaitu aplikasi Macromedia Flash. Alasan pemilihan software Macromedia Flash karena aplikasi ini mampu menghasilkan presentasi interaktif yang di dalamnya mencakup video, teks, gambar, desain, audio, soal evaluasi interaktif, dan animasi sehingga lebih menarik. Dan juga aplikasi ini cukup mudah digunakan oleh guru maupun peserta didik, hanya perlu menginstal software Macromedia Flash dengan begitu siswa dapat langsung membuka file pembelajaran yang diberikan oleh guru.

Berdasarkan hasil dari pada observasi dan paparan permasalahan yang telah di jelaskan, peneliti bermaksud untuk membuat penelitian berupa penelitian dan pengembangan (Research \& Development) yang berjudul "Pengembangan Media Interaktif berbasis Macromedia Flash 
Materi Kewargaan Digital di SMK Pasim Plus Sukabumi”.

\section{METODOLOGI PENELITIAN}

Metode penelitian ini menggunakan model penelitian dan pengembangan (Reasearch and Development). Metode penelitian dan pengembangan atau dalam bahasa Inggrisnya Research \& Development adalah metode penelitian yang digunakan untuk menghasilkan produk tertentu, dan menguji keefektifan produk tersebut (Sugiyono, 2016:297).

Langkah - langkah dalam penelitian ini meliputi:

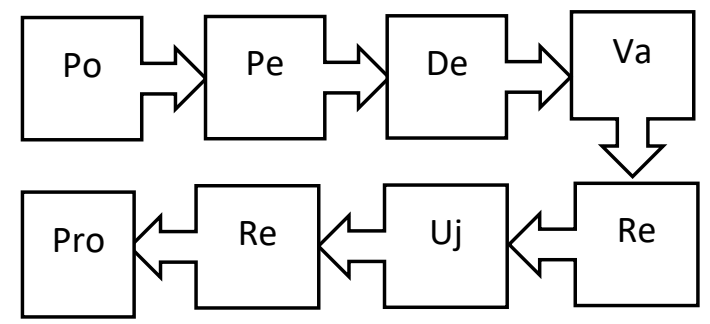

Ket:

Po: Potensi dan Masalah

Pe: Pengumpulan Data

De: Desain Produk

Va Validasi Desain

Re: Revisi Desain

Uj: Uji Coba Produk

Re: Revisi Produk

Pro: Produksi Masal

Namun karena keterbatasan waktu dan biaya penelitian ini hanya dilakukan pada tahap uji coba produk.

Metode pengumpulan data yang digunakan adalah observasi, wawancara, dan kuesioner dengan menggunakan instrumen pengumpulan data berupa lembar validasi ahli media, lembar validasi ahli materi, serta angket respon pengguna (peserta didik). Adapun peserta didik yang dimaksud ialah peserta didik SMK Pasim Plus Sukabumi berjumlah 8 orang dalam pengujian uji coba lapangan kelas kecil.

Data kelayakan produk nantinya didapatkan dari hasil uji validasi ahli dan uji kelayakan oleh pengguna (peserta didik). Skor yang diperoleh dikonversikan menjadi data kualitatif skala lima dengan acuan rumus yang diadaptasi dari Sarifuddin Azwar dalam Dedy Irawan (85:2020). Berikut konversi skor aktual yang sudah dimodifikasi seperti pada tabel berikut ini.

Tabel 1 Modivikasi Konversi Skor Aktual Menjadi Skala Lima

\begin{tabular}{|c|c|c|c|}
\hline No & $\begin{array}{c}\text { Interval } \\
\text { Skor }\end{array}$ & Nilai & Kategori \\
\hline 1 & $\begin{array}{l}\mathrm{X}>\mathrm{Xi}+ \\
1,5 \mathrm{SBi}\end{array}$ & $>4,05$ & $\begin{array}{l}\text { Sangat } \\
\text { Layak }\end{array}$ \\
\hline 2 & $\begin{array}{l}\mathrm{Xi}+\mathrm{SBi}< \\
\mathrm{X} \leq \mathrm{Xi}+1,5 \\
\mathrm{SBi}\end{array}$ & $\begin{array}{c}>3,7- \\
4,05\end{array}$ & Layak \\
\hline 3 & $\begin{array}{l}\mathrm{Xi}-0,5 \\
\mathrm{SBi}<\mathrm{X} \leq \\
\mathrm{Xi}+\mathrm{SBi}\end{array}$ & $\begin{array}{c}>2,65- \\
3,7\end{array}$ & $\begin{array}{l}\text { Cukup } \\
\text { Layak }\end{array}$ \\
\hline 4 & $\begin{array}{l}\mathrm{Xi}-1,5 \\
\mathrm{SBi}<\mathrm{X} \leq \\
\mathrm{Xi}-0,5 \\
\mathrm{SBi}\end{array}$ & $\begin{array}{c}>1,95- \\
3,7\end{array}$ & $\begin{array}{c}\text { Kurang } \\
\text { Layak }\end{array}$ \\
\hline 5 & $\begin{array}{l}\mathrm{X} \leq \mathrm{Xi}- \\
1,5 \mathrm{SBi}\end{array}$ & $\geq 1,95$ & $\begin{array}{l}\text { Tidak } \\
\text { Layak }\end{array}$ \\
\hline
\end{tabular}


Keterangan:

$\mathrm{X} \quad$ : Skor empiris (skor aktual)

$\mathrm{Xi} \quad:$ Rerata ideal $=\frac{1}{2}($ skor maksimal + skor minimal)

$\mathrm{SBi} \quad$ : Simpangan Baku ideal $=\frac{1}{6}($ skor maksimal - skor minimal)

Kategori kelayakan didefinisikan kembali menjadi:
A $\quad$ : Sangat Setuju = Sangat Layak
B : Setuju $=$ Layak
C $\quad$ : Netral $=$ Cukup Layak
D $\quad$ : Tidak Setuju $=$ Kurang Layak
E $\quad$ : Sangat Tidak Setuju $=$ Tidak Layak

Penilaian produk pada penelitian ini ditentukan dengan nilai minimal 3,7 yaitu kategori layak. Apabila hasil dari ahli media dan ahli materi mendapat kategori layak maka produk layak di uji cobakan di lapangan, lalu jika hasil penilaian dari pengguna (peserta didik) mendapat kategori layak maka produk media pembelajaran interaktif materi Kewargaan Digital layak digunakan sebagai media pembelajaran di kelas X OTKP 1 SMK Pasim Plus Sukabumi.

\section{HASIL PENELITIAN DAN}

\section{PEMBAHASAN}

Produk yang dihasilkan dalam penelitian ini yaitu media pembelajaran interaktif pada mata pelajaran Simulasi dan Komunikasi Digital yang dibuat menggunakan aplikasi Macromedia Flash. Selanjutnya media divalidasi kepada ahli media dan ahli materi serta diuji cobakan kepada peserta didik kelas X OTKP 1 Smk Pasim Plus Sukabumi berjumlah 8 orang. Berikut hasilnya:

\section{Validasi Ahli Media}

Validasi oleh ahli media dilakukan untuk mengetahui tingkat kelayakan media pembelajaran interaktif yang dikembaangkan dari aspek media. Penilaian media pembelajaran oleh ahli media ditinjau dan dinilai dari aspek Perangkat Lunak dan aspek Komunikasi Visual, dengan 15 indikator. Berikut saran perbaikan yang perlu diperbaiki menurut ahli media:

\section{Gambar 1 Tampilan Awal Media}

\section{Sebelum Divalidasi oleh Ahli Media}

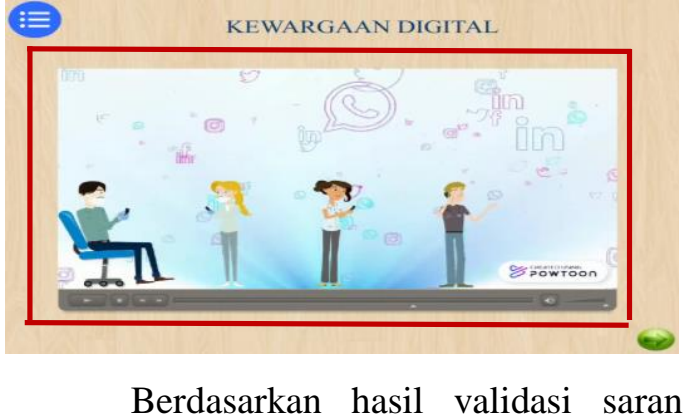

perbaikan yang diberikan oleh ahli media yaitu untuk mengganti media penyampaian materi dari animasi menjadi video pembelajaran. Dikarenakan animasi yang dipakai berdurasi sangat cepat yaitu hanya 20 detik.

\section{Gambar 2 Tampilan Media Setelah} Divalidasi oleh Ahli Media

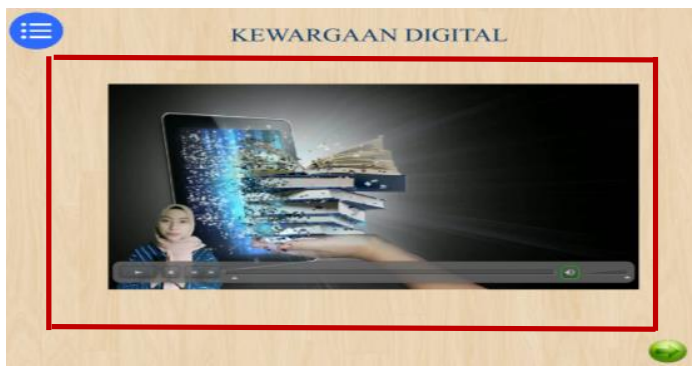


Penggantian media materi dari bentuk animasi menjadi video pembelajaran dengan durasi yang lebih lama yaitu dengan durasi berkisar 1 menit 17 detik hingga 6 menit 45 detik.

Penilaian media pembelajaran oleh ahli media ditinjau dan dinilai dari aspek Perangkat Lunak dan aspek Komunikasi visual, dengan 15 indikator. Berikut keseluruhan skor yang diperoleh.

\section{Tabel 1 Hasil Validasi Ahli Media}

\begin{tabular}{|c|c|c|c|c|}
\hline $\begin{array}{c}\text { Aspek } \\
\text { Penilaian }\end{array}$ & $\begin{array}{c}\text { Juml } \\
\text { ah } \\
\text { Butir }\end{array}$ & $\begin{array}{c}\text { Skor } \\
\text { yang } \\
\text { diperol } \\
\text { eh }\end{array}$ & $\begin{array}{c}\text { Sk } \\
\text { or } \\
\text { Ide } \\
\text { al }\end{array}$ & $\begin{array}{c}\text { Kelaya } \\
\text { kan }\end{array}$ \\
\hline $\begin{array}{c}\text { Perangka } \\
\text { t Lunak }\end{array}$ & 5 & 19 & 25 & $\begin{array}{c}76 \% \\
(3.8)\end{array}$ \\
\hline $\begin{array}{c}\text { Komuni } \\
\text { kasi } \\
\text { Visual }\end{array}$ & 10 & 43 & 50 & $\begin{array}{c}86 \% \\
(4.3)\end{array}$ \\
\hline Jumlah & 15 & 62 & 75 & $\begin{array}{c}83 \% \\
(4.13)\end{array}$ \\
\hline \multicolumn{3}{|c}{ Kategori } & $\begin{array}{c}\text { Sangat } \\
\text { Layak }\end{array}$ \\
\hline
\end{tabular}

Berdasarkan perhitungan pada tabel, validasi oleh ahli media mendapatkan nilai 4,13 dari skala 5 atau $83 \%$ dengan kategori "Sangat Layak",

\section{Validasi Ahli Materi}

Validasi oleh ahli materi ditujukan untuk mengetahui tingkat kelayakan media pembelajaran interaktif yang dikembangkan dari aspek materi. Penilaian media pembelajaran oleh ahli materi ditinjau dan dinilai dari aspek materi, aspek soal, dan aspek bahasa dengan 16 indikator.

Berdasarkan hasil validasi oleh ahli materi tidak ada materi yang perlu diubah. Berikut keseluruhan skor yang diperoleh.

Tabel 2 Hasil Validasi Ahli Materi

\begin{tabular}{|c|c|c|c|c|}
\hline $\begin{array}{c}\text { Aspek } \\
\text { Penilaian }\end{array}$ & $\begin{array}{c}\text { Jum } \\
\text { lah } \\
\text { But } \\
\text { ir }\end{array}$ & $\begin{array}{l}\text { Skor } \\
\text { yang } \\
\text { diper } \\
\text { oleh }\end{array}$ & $\begin{array}{l}\text { Skor } \\
\text { Ideal }\end{array}$ & $\begin{array}{c}\text { Kelayak } \\
\text { an }\end{array}$ \\
\hline Materi & 9 & 45 & 45 & $\begin{array}{c}100 \% \\
(5)\end{array}$ \\
\hline Soal & 5 & 20 & 20 & $\begin{array}{c}100 \% \\
(5)\end{array}$ \\
\hline Bahasa & 2 & 10 & 20 & $\begin{array}{c}100 \% \\
(5)\end{array}$ \\
\hline Jumlah & 16 & 75 & 85 & $\begin{array}{c}100 \% \\
(5)\end{array}$ \\
\hline \multicolumn{4}{|c|}{ Kategori } & $\begin{array}{l}\text { Sangat } \\
\text { Layak }\end{array}$ \\
\hline
\end{tabular}

Berdasarkan perhitungan pada tabel, validasi oleh ahli materi mendapatkan nilai 5 dari skala 5 atau $100 \%$ dengan kategori "Sangat Layak".

\section{Uji Coba Lapangan}

Pada tahap ini produk yang telah selesai dikembangkan lalu dilakukan uji coba kelas kecil kepada peserta didik kelas $\mathrm{X}$ OTKP 1 SMK Pasim Plus Sukabumi untuk mengetahui tanggapan pengguna mengenai media pembelajaran interaktif materi Kewargaan Digital. Hasil penilaian uji coba lapangan tersebut dapat dilihat dari tabel berikut 
Tabel 3 Hasil Penilaian Peserta Didik

Pada Uji Coba Kelas Kecil

\begin{tabular}{|c|c|c|c|}
\hline No & Indikator & Rerata & Kriteria \\
\hline 1 & $\begin{array}{l}\text { Aplikasi dapat } \\
\text { dioperasikan } \\
\text { dengan mudah }\end{array}$ & 3.9 & Layak \\
\hline 2 & $\begin{array}{l}\text { Media tidak } \\
\text { berhenti } \\
\text { (hang) saat } \\
\text { dijalankan }\end{array}$ & 3.5 & Layak \\
\hline 3 & $\begin{array}{l}\text { Materi yang } \\
\text { disajikan } \\
\text { dalam media } \\
\text { mudah } \\
\text { dipahami }\end{array}$ & 3.5 & Layak \\
\hline 4 & $\begin{array}{l}\text { Materi } \\
\text { disajikan } \\
\text { secara runtut }\end{array}$ & 3.5 & Layak \\
\hline 5 & $\begin{array}{l}\text { Bahasa yang } \\
\text { digunakan } \\
\text { komunikatif }\end{array}$ & 4.3 & $\begin{array}{l}\text { Sangat } \\
\text { Layak }\end{array}$ \\
\hline 6 & $\begin{array}{l}\text { Alur } \\
\text { penyampaian } \\
\text { materi dalam } \\
\text { media runtut } \\
\text { dan jelas }\end{array}$ & 4.3 & $\begin{array}{l}\text { Sangat } \\
\text { Layak }\end{array}$ \\
\hline 7 & $\begin{array}{l}\text { Perumusan } \\
\text { soal mudah } \\
\text { dipahami }\end{array}$ & 3.8 & Layak \\
\hline 8 & $\begin{array}{l}\text { Soal dalam } \\
\text { media sesuai } \\
\text { dengan materi }\end{array}$ & 3.8 & Layak \\
\hline 9 & $\begin{array}{l}\text { Musik tidak } \\
\text { mengganggu }\end{array}$ & 3.8 & Layak \\
\hline
\end{tabular}

\begin{tabular}{|c|c|c|c|}
\hline 10 & $\begin{array}{l}\text { Tulisan dapat } \\
\text { dibaca dengan } \\
\text { jelas }\end{array}$ & 4.4 & $\begin{array}{l}\text { Sangat } \\
\text { Layak }\end{array}$ \\
\hline 11 & $\begin{array}{l}\text { Tampilan } \\
\text { menarik }\end{array}$ & 4.3 & $\begin{array}{l}\text { Sangat } \\
\text { Layak }\end{array}$ \\
\hline 12 & $\begin{array}{l}\text { Tombol } \\
\text { berfungsi } \\
\text { dengan baik }\end{array}$ & 4.3 & $\begin{array}{l}\text { Sangat } \\
\text { Layak }\end{array}$ \\
\hline 13 & $\begin{array}{l}\text { Visualisasi } \\
\text { menarik }\end{array}$ & 4.1 & $\begin{array}{l}\text { Sangat } \\
\text { Layak }\end{array}$ \\
\hline 14 & $\begin{array}{l}\text { Aplikasi } \\
\text { media } \\
\text { pembelajaran } \\
\text { ini kreatif dan } \\
\text { inovatif }\end{array}$ & 3.9 & Layak \\
\hline & Rerata Total & & \\
\hline & Kriteria Total & \multicolumn{2}{|c|}{ Layak } \\
\hline
\end{tabular}

Berdasarkan hasil perhitungan dari tabel diatas dengan hasil penilaian dari 8 peserta didik diperoleh nilai 4 dari skala 5 dengan kategori "Layak", sehingga media pembelajaran interaktif ini layak untuk digunakan dalam pembelajaran Simulasi dan Komunikasi Digital untuk materi Kewargaan Digital di SMK Pasim Plus Sukabumi.

\section{KESIMPULAN}

Kesimpulan yang didapat oleh peneliti berdasarkan hasil penelitian dan pengembangan media pembelajaran interaktif materi Kewargaan Digital diantaranya:

1. Hasil produk dalam penelitian ini adalah media pembelajaran interaktif materi 
Kewargaan Digital untuk peserta didik kelas X OTKP 1 Sukabumi.

2. Langkah - langkah penelitian dan pengembangan media pembelajaran interkatif ini ]menggunakan pengembangan R\&D meliputi: Potensi dan Masalah, Pengumpulan Data, Desain Produk, Validasi Desain, Revisi Desain, Uji Coba Produk, Revisi Produk, Pembuatan Produksi Masal. Dari 8 langkah tersebut peneliti hanya dapat menyelesaikan hingga tahap ke-7 karena keterbatasan waktu dan biaya.

3. Kelayakan media pembelajaran interaktif materi Kewargaan Digital diperoleh dari instrumen penilaian validasi ahli media dan ahli materi, serta hasil penilaian peserta didik dalam uji coba lapangan kelas kecil. Penilaian dari ahli media mendapatkan skor 4,13 dari skala 5 dengan kategori sangat layak. Penilaian dari ahli materi mendapatkan skor 5 dari skala 5 dengan kategori sangat layak. Penilaian oleh peserta didik dalam uji coba lapangan kelas kecil mendapatkan skor 4 dari skala 5 dengan kategori layak. Dengan demikian media pembelajaran interaktif ini mendapat kategori "Sangat Layak" dan dapat digunakan dalam pembelajran untuk materi Kewargaan Digital di kelas X OTKP 1 SMK Pasim Plus Sukabumi.

\section{DAFTAR PUSTAKA}

Budiman, H. (2017). Peran Teknologi Informasi Dan Komunikasi Dalam
Pendidikan. Haris Budiman., 8(I), 31-43.

Irawan, Dedy. (2020). Mengembangkan Buku Teks Pelajaran Membaca Berbasis Pendekatan Proses Untuk SD. Purwokerto: CV. Pena Persada.

Muhson, A. (2010). Pengembangan Media Pembelajaran Berbasis Teknologi Informasi, VIII(2).

Sugiyono. (2016). Metode Penelitian Kuantitatif, Kualitatif, dan R\&D. Bandung: Alfabeta CV.

Triwiyanto, Teguh. (2014). Pengantar Pendidikan. Jakarta: Perpustakaan Nasional: Katalog Dalam Terbitan (KDT). 